\title{
MEDIA AUDIO VISUAL DALAM PEMBELAJARAN PAI
}

\author{
Umar Manshur, Maghfur Ramdlani \\ Universitas Nurul Jadid \\ umarmanshur@yahoo.co.id,maghfurramdani@gmail.com
}

\begin{abstract}
:
Advances in science and technology, especially information technology, greatly influenced the preparation and implementation of learning strategies. Through this progress teachers can use various media in accordance with the needs and learning objectives. Using communication media can not only simplify and streamline the learning process, but can also make the learning process more interesting. According to Sanjay the learning process is a communication process. In a communication process always involves three main components, namely the component of the sender of the message (teacher), the component of the recipient of the message (students), and the component of the message itself which is usually in the form of subject matter. Sometimes in the learning process communication fails. This means that the subject matter or message conveyed by the teacher cannot be received by students optimally, meaning that not all subject matter can be understood properly by students; Worse yet, students as recipients of messages misrepresented the contents of the message delivered. To avoid all that, the teacher can develop learning strategies by utilizing various media and learning resources.

Keywords: $\mid$ Islamic Education, Audio Visual Media
\end{abstract}

\section{PENDAHULUAN}

Perkembangan pengetahuan dan teknologi telah membawa perubahan yang sangat signifikan terhadap berbagai dimensi kehidupan manusia pada era ini, khususnya dibidang pendidikan. Oleh karena itu, agar pendidikan tidak tertinggal dari perkembangan ilmu pengetahuan maka diperlukan penyesuaian. Teknologi yang ada harus dimanfaatkan untuk membantu proses pembelajaran dalam pendidikan yang ada di sekolah-sekolah. Penggunaan media pembelajaran dalam pendidikan harus disesuaikan dengan materi ajar agar penggunaannya dapat proporsional. Media pembelajaran saat ini mengalami pengembangan yang sangat drastis. Berawal dari penggunaan media berbasis manusia hingga berkembang sampai media yang sangat kompleks yang digunakan dalam proses pembelajaran. Semua pengembangan itu, tak lain yaitu untuk memajukan pendidikan yang ada saat ini.

Penggunaan media pembelajaran dalam pendidikan haruslah disesuaikan dengan materi ajar agar penggunaannya dapat proporsional. Media pembelajaran saat ini telah mengalami pengembangan yang sangat drastis. Bermula dari penggunaan media berbasis manusia yang kemudian berkembang sampai media yang sangat kompleks dalam proses pembelajaran.

Semua pengembangan itu, tak lain yaitu untuk memajukan pendidikan yang ada saat ini. Dalam proses belajar mengajar, kehadiran alat/media mempunyai arti yang cukup penting. Karena dalam kegiatan tersebut, ketidakjelasan bahan yang disampaikan dapat dibantu dengan menghadirkan media sebagai perantara. Namun, meskipun begitu pentingnya alat/media bagi tercapainya tujuan pendidikan, masih banyak dijumpai lembaga-lembaga pendidikan yang kurang mementingkan suatu alat/media tersebut. Terbukti banyak temuan pendidik yang tidak mempergunakan media 
sesuai dengan bahan yang diajarkan seperti dalam pembelajaran pendidikan agama Islam, peserta didik mengalami banyak kesulitan dalam memahami pelajaran yang disampaikan, pendidik kesulitan menyampaikan bahan pelajaran sehingga banyak peserta didik yang merasa jenuh terhadap pelajaran pendidikan agama Islam. Hal ini dapat diidentifikasikan sebagai masalah yaitu pada kurangnya pemahaman pendidik dalam pengaplikasian media dalam pembelajaran tersebut.

\section{Struktur Mata Pelajaran PAI}

Pendidikan agama Islam (PAI) adalah upaya sadar dalam menyiapkan peserta didik untuk mengenal, memahami, menghayati, hingga mengimani ajaran agama Islam, bersamaan dengan tuntutan untuk menghormati penganut agama lain dalam hubungannya dengan kerukunan antar umat beragama hingga terwujud kesatuan dan persatuan bangsa. dan untuk mencapai pengertian tersebut maka harus ada serangkaian yang saling mendukung antara lain :

1. Pendidikan agama Islam sebagai usaha sadar, yaitu suatu kegiatan bimbingan, pengajaran dan atau latihan yang dilakukan secara sadar akan tujuan yang akan dicapai.

2. Peserta didik yang akan disiapkan untuk mencapai tujuan, dalam arti yang dibimbing, diajari dan atau dilatih dalam peningkatan keyakinan, pemahaman, penghayatan dan pengamalan terhadap ajaran agama Islam.

3. Pendidik/ Guru (GBPAI) yang melakukan kegiatan bimbingan, pengajarandan atau latihan secara sadar terhadap peserta didiknya untuk mencapaitujuan tertentu. Kegiatan PAI diarahkan agar dapat meningkatkan keyakinan, pemahaman, penghayatan, dan pengamalan terhadap peserta didik, yang disamping untuk membentuk kualitas pribadi, sekaligus untuk membentuk kesalehan atau kualitas pribadi, juga membentuk kesalehan sosial.

Menurut (Drajat, 2020) yang dikutip oleh Abdul Majid dan Dian Andayani, "Pendidikan agama Islam adalah suatu usaha untuk membina dan mengasuh peserta didik agar senantiasa dapat memahami ajaran Islam secara menyeluruh, menghayati tujuan, yang pada akhirnya dapat mengamalkan serta menjadikan Islam sebagai pandangan hidup". Dalam kegiatan pembelajaran, peserta didik difasilitasi untuk terlibat secara aktif mengembangkan potensi dirinya menjadi kompetensi. Guru menyediakan pengalaman belajar bagi peserta didik untuk melakukan berbagai kegiatan yang memungkinkan mereka mengembangkan potensi yang dimiliki mereka menjadikompetensi yang ditetapkan dalam dokumen kurikulum atau lebih. Pengalaman belajar tersebut semakin lama semakin meningkat menjadi kebiasaan belajar mandiri dan ajeg sebagai salah satu dasar untuk belajar sepanjang hayat. Pada Kurikulum 2013 dikembangkan dua macam proses pembelajaran yaitu proses pembelajaran langsung dan proses pembelajaran tidak langsung. Proses pembelajaran langsung merupakan proses pendidikan dimana peserta didik mengembangkan pengetahuan, kemampuan berpikir dan keterampilan psikomotorik melalui interaksi langsung dengan sumber belajar yang dirancangdalam dalam silabus dan RPP yang berupa kegiatan-kegiatan pembelajaran. Dalam pembelajaran PAI, agar bahan pelajaran yang diberikan lebih mudah untuk dipahami oleh siswa, diperlukan media yang membantu dalam proses penyampaian tersebut. Melalui media (alat bantu), diharapkan akan terjadi persepsi yang sama antara guru dan siswa. mengingat Pendidikan Agama Islam adalah pendidikan yang sangat penting bagi kehidupan manusia, terutama dalam mencapai ketentraman batin dan kesehatan mental pada umumnya. Agama Islam merupakan bimbingan hidup yang paling baik, pencegah perbuatan salah dan munkar yang paling ampuh, pengendali moral yang tiadataranya. Untuk itu diperlukan kemampuan guru dalam menyampaikan materi/ajaran-ajaran agama Islam agar mudah 
diterima dan tidak menimbulkan salah persepsi bagi siswa dalam mengamalkan ajaran agama Islam (Ermawati, 2014)

\section{Media Pembelajaran PAI}

Media pembelajaran merupakan salah faktor penting dalam peningkatan kualitas pembelajaran. Hal tersebut dikarenakan pesatnya perkembangan teknologi dalam bidang pendidikan yang menuntut efisiensi dan efektivitas dalam pembelajaran. Untuk mencapai tingkat efisiensi dan efektivitas yang optimal, maka salah satu upaya yang harus dilakukan adalah mengurangi dominasi sistem penyampaian pelajaran yang bersifat verbalistik dengan cara menggunakan media pembelajaran. Media pembelajaran merupakah segala sesuatu yang mampu menyampaikan pesan (materi pembelajaran), sehingga mampu merangsang perhatian, minat, pikiran, dan perasaan siswa dalam kegiatan belajar untuk mencapai tujuan belajar. Audio berarti radio (suara) dan visual berarti grafik, gambar, yang dapat dilihat. Jadi audio visual berarti kombinasi antara gambar dan suara.

Menurut (Ely, 1980) media apabila dipahami secara garis besar adalah manusia, materi atau kejadian yang membangun kondisi yang membuat siswa mampu memperoleh pengetahuan, keterampilan atau sikap. Pengembangan media pembelajaran merupakan usaha penyusunan program media pembelajaran yang lebih tertuju pada perencanaan media pembelajaran. Media yang akan ditampilkan atau akan digunakan dalam proses belajar mengajar terlebih dahulu direncanakan dan dirancang sesuai dengan kebutuhan lapangan atau siswanya (Zain, 2002).

Proses pembelajaran merupakan sebuah proses komunikasi antara guru dan peserta didik melalui bahasa verbal sebagai media utama penyampaian materi pembelajaran. Dalam kondisi seperti ini, proses pembelajaran akan tergantung kepada guru sebagai sumber belajar. Namun demikian, kondisi dilapangan tidak semua bahan pelajaran dapat disajikan oleh guru secara langsung. Untuk mempelajari bagaimana kehidupan makhluk hidup di dasar laut, tidak mungkin guru membimbing siswa langsung dengan membelah dada manusia hanya untuk mempelajari cara kerja organ tubuh manusia. Akan tetapi guru dapat menggunakan berbagai macam alat bantu dalam menyampaikan pengejaran. Alat bantu belajar yang dimaksud dengan media atau alat peraga pembelajaran (Sanjaya, 2011) Terkait dengan pembelajaran Pendidikan Agama Islam, maka media yang digunakan juga beragam. dalam dunia pendidikan dapat diidentifikasikan dengan istilah "demonstrasi” yaitu memberikan contoh dan menunjukkan tentang cara berbuat atau melakukan sesuatu. Media ini sering digunakan oleh Nabi dalam mengajarkan ajaran ajaran agama kepada umatnya, misalnya dalam mempraktekkan sholat dan lain-lain. Selanjutnya, melalui suri tauladan atau model perbuatan dan tindakan yang baik, maka guru agama akan dapat menumbuhkembangkan sifat dan sikap yang baik pula terhadap anak didik. Oleh karena itu, media Pendidikan Agama Islam dapat dimaknai sebagai aktifitas yang berhubungan dengan materi pendidikan agama Islam, baik yang berupa alat yang dapat diperagakan maupun metode yang secara efektif dapat digunakan oleh guru agama dalam rangka mencapai tujuan tertentu (Ramayulis, 2002).

Sehubungan dengan penggunaan media dalam kegiatan pembelajaran, para tenaga pengajar atau guru perlu cermat dalam pemilihan dan atau penetapan media yang akan digunakannya. ketepatan dalam memilih media akan menunjang efektivitas kegiatan pembelajaran yang dilakukan. Selain itu juga kegiatan pembelajaran menjadi menarik sehingga dapat menimbulkan motivasi belajar. ketepatan dalam memilih media pembelajaran dipengaruhi 
oleh banyak faktor seperti luas sempitnya pengetahuan tenaga pengajar tentang kriteria atau faktor-faktor yang perlu dipertimbangkan dan prosedur pemilihan media pembelajaran. Sebenarnya media pembelajaran merupakan perantara untuk mempermudah dalam menyampaikan pesan bagi guru kepada siswa.

Dalam perkembangan teknologi yang pesat ini, berkembang pula media dalam pembelajaran. Tentu terdapat kekurangan dan kelebihan dalam media. Maka guru dituntut untuk mampu memilih dengan efektif dan efesien. Uraian berikut akan membahas hal-hal dimaksud agar kita dalam memilihan media pembelajaran lebih tepat. Sebelum mempertimbangkan untuk memilih media pembelajar guru dituntut untuk meyakini bahwa media adalah sebuah perantara untuk mempermudah dalam menyampaikan pesan. Pesan yang akan disampaikan agar sesuai dengan yang diinginkan atau tepat pada siswa..

Dalam pertimbangan memilih media. Pertama: Guru hendaknya merasa sudah akrab dengan media tersebut.karena ini akan menjadikan kegiatan yang efektif dan terkendali karena sudah dikenal medianya dan dapat dikuasai. Kedua: Merasa bahwa media yang digunakan dapat berbuat lebih dari yang bisa dilakukannya. dengan penggunaan media tertentu guru dan siswa dapat mencapai tarjet tertentu atau bahkan lebih dari target yang diinginkan. Ketiga: Media yang dipilihnya dapat menarik minat dan perhatian siswa. Dengan media ini perhatian siswa bias terfokur pada guru dalam menyampaikan pesan. Siswa termotivasi dan kagum untuk mau belajar dan mengembangkan pengetahuan sebagaimana yang disampaiakan guru di depan kelas. Guru mampu memfokuskan perhatian siswa adalah salah satu indikator keefektifan komunikasi dalam pendidikan.

\section{Media Audio Visual Dalam Pembelajaran PAI}

Pembahasan pembelajaran dengan menggunakan media audio tidak lepas dari aspek pendengaran itu sendiri. Pendengaran merupakan alat untuk mendengarkan. Mendengarkan sesungguhnya suatu proses yang rumit yang melibatkan empat unsur : 1) mendengar, 2) memperhatikan, 3) memahami dan 4) unsur mengingat. maka dengan demikian mendengarkan merupakan proses selektif untuk memperhatikan, mendengar, memahami dan mengingat simbolsimbol pendengaran (Munadi, 2013). Media audio memiliki kemampuan media untuk membangkitkan rangsangan indera pendengaran.

Pengintegrasiannya bisa secara murni, akan tetapi bisa juga semi terintegrasi. Pengintegrasian secara murni artinya antar bahan pembelajaran yang tidak dapat di pisahpisahkan. Peserta didik harus memiliki dan memanfaatkan keduanya dalam proses pembelajaran. Model kedua adalah melalui media audio peserta didik diajak untuk berpartisipasi dalam kegiatan pembelajaran.

Adapun kekurangan dari media audio ini adalah sifat komunikasinya yang satu arah. Dan penyajiannya hanya mengandalkan satu indera (Yuhdi, 2013). Dalam hal pembelajaran mata pelajaran pendidikan agama islam dimadrasah guru dapat menggunakan media audio untuk kepentingan pembelajaran.

Beberapa materi pendidikan agama islam yang dapat terapkan dengan menggunakan media audio adalah sebagai berikut:

1. Materi SKI menurut penulis dapat digunakan menggunakan media audio yaitu dengan membuat drama atau sandiwara audio dengan durasi 15 sampai 20 menit. Guru dapat membuat drama dan atau sandiwara dalam bentuk rekaman audio. Adapun para pemainnya 
adalah dari siswa. Program drama/sandiwara radio ini dapat memberikan manfaat cukup baik bagi siswa pada pemahaman peristiwa-peristiwa sejarah.

2. Mata pelajaran fiqih pun dapat menggunakan media audio yaitu dengan membuat materi menjadi materi talk show misalnya pembahasan tentang pengertian zakat, pajak, sedekah dan infaq.

3. Adapun untuk mata pelajaran al-qur'an hadits media audio daat digunakan sebagai fasilitator dari mualai mengenal huruf hijaiyah sampai dengan media membaca al-qur'an sesuai dengan kaidah tajwid.

4. Demikian juga dengan mata pelajaran akidah akhlak materi dapat di modifikasi menjadi talk show yang membahas berbagai pokok bahasan dalam materi akidah akhlak.

5. Mata pelajaran bahasa arab termasuk dalam rumpun mata pelajaran pendidikan agama islam dan penggunaan media audio sangat sesuai untuk pelajaran bahasa arab. Dengan media ini siswa dapat mempelajari/ mendengarkan ungkapan-uangkapan dari native speaker, siswa juga dapat membelajari intonasi bahasa yang digunakan oleh native speaker. Peserta didik juga dapat berlatih pidato ahasa arab dengan media audio ini.

\section{MEDIA VISUAL}

Media berbasis visual memegang peranan penting dalam proses belajar. Media visual dapat pula mempermudah pemahaman dan memperkuat ingatan. Visual mampu menumbuhkan minat siswa dan dapat memberikan hubungan antara materi dengan dunia nyata. Agar menjadi efektif visual sebaiknya ditempatkan pada konteks yang bermakna dan siswa harus berinteraksi dengan visual tersebut untuk meyakinkan terjadinya proses informasi (Arsyad, 2010).

Menurut (Munadi, 2013) media visual adalah media yang melibatkan indera pengelihatan. Bentuk visual dapat berupa gambar presentasi seperti gambar, lukisan atau foto yang menunjukkan bagaiman tampaknya sesuatu benda. Bentuk visual dapat juga berbentuk diagram yang melukiskan hubungan - hubungan konsep, organisasi, dan struktur materia. Bentuk lain dari media visual adalah peta yang menunjukkan hubungan antara unsurunsur dalam isi materi, grafik pun masuk dalam kategori media visual.

Dalam pembelajaran media visual sangat memungkinkan untuk disajikan dalam mata pelajaran pendidikan agama islam di madrasah ataupun disekolah. Berikut ini beberapa contoh yang dapat penulis berikan sebagai bentuk pemanfaatan media visual. Pemanfaatan media visual dapat digunakan untuk mata pelajaran sejarah kebudayaan islam. Seperti pada pembahasan kondisi arab sebelum islam, pokok bahasan ini dapat di buat media dalam bentuk poster.

Dengan poster tersebut siswa bisa diberikan stimulus untuk menceritakan pokok bahasan yang dibahas kemudian siswa mempresentasikan informasi yang telah ditemukannya. Selain mata pelajaran sejarah kebudayaan islam mata pelajaran fiqih pun dapat memanfaatkan media visual ini misalnya pada pokok bahasan shalat wajib dapat disediakan gambar tentang tata cara shalat, ataupun tata cara wudhu haji dan lain sebagainya. Pada mata pelajaran alqur'an hadits dapat diterapkan media ini seperti penyajian tabel tentang hukum bacaan alqur'an dan sebagainya. Demikian juga dengan mata pelajaran akidah akhlak pokok bahasan yang membahas tentang nama-nama Allah. 


\section{MEDIA AUDIO VISUAL}

Media audio visual adalah jenis media yang lain mengandung unsur suara juga mengandung unsur gambar yang bisa dilihat, seperti misalnya rekaman video, berbagai ukuran film, slide suara dan lain sebagainya. Kemampuan media ini dinggap lebih baik dan lebih menarik . Sementara menurut (Munadi, 2013) media audio visual dapat dibagi menjadi dua jenis. Jenis pertama, dinamakan media audio-visual murni, seperti film gerak (movie) bersuara, televisi dan video.

Jenis kedua adalah audio visual tidak murni yankni apa yang kita kenal dengan slide, opaque, ohp dan pralatan visual lainnya, bila diberi unsur suara dari rekaman kaset yang dimanfaatkan secara bersamaan dalam satu waktu atau proses pembelajaran. Pemanfaatan media audio visual berupa film yang merupakan alat komunikasi yang sangat membantu proses pembelajaran efektif. Apa yang terpandang oleh mata dan terdengat oleh telinga, lebih cepat dan lebih mudah diingat daripaa apa yang hanya dibaca saja atau didengar saja.

Adapun manfaat dan karakteristik dari film adalah sebagai berikut:

1. Mengatasi keterbatasan jarak dan waktu

2. Mampu menggambarkan peristiwaperistiwa msa lalu secara realistis dalam waktu yang singkat.

3. Film dapat membawa anak dari negara yang satu ke negara yang lain dan dari masa yang satu ke masa yang lain.

1. Film dapat diulangi bila perlu untuk menambah kejelasan

2. Pesan yang akan disampaikan cepat dan mudah diingat

3. Mengembangkan pikiran dan dan pendapat para siswa

4. Mengembangkan imajinasi persrta didik.

5. Memperjelas hal-hal yang yang abstrak dan memberikan gamaran yang lebih realistis

6. Sangat kuat mempengaruhi emosi seseorang

7. Film sangat baik untuk menjelaskan suatu proses dan dapat menjelaskan suatu proses dan dapat menjelaskan suatu keterampilan dan lain-lain.

8. Semua peserta didik dapat belajar dari film, baik yang panai maupun yang kurang pandai.

9. Menumbuhkan minat dan motivasi belajar.

Selain kelebihan memiliki kelebihan, media audio visual juga memiliki kelemahan yaitu media audio visual terlalu menekankan pentingnya materi ketimbang proses pengembangan materi tersebut.

Hal lain adalah bahwa pembuatan dan penggunaan media audio visual dalam proses pembelajaran terutama dinegara kita masih sangat minim (sedikit), hal ini karena media audio visual ini masih tergolong mahal atau memakan biaya yang tinggi. Menurut Oemar Hamalik sebagaimana yang dikutif oleh Asnawir (2002) menyatakan bahwa film yang baik memiliki ciri-ciri sebagai berikut :

1. Dapat menarik siswa

2. Benar dan autentik

3. Up to date dalam setting, pakaian, dan lingkungan

4. Perbendaharaan bahasa yang dipergunakan secara benar

5. Kesatuan dan sequence nya cukup teratur 
6. Teknis yang dipergunakan cukup memenuhi persyaratan dan cukup memuaskan. Adapun langkah-langkah pemanfaatan film menurut (Munadi, 2013) dalam proses pembelajaran hendaknya memperhatikan hal-hal sebagai berikut :

1. Film haru dipilih agar sesuai dengan tujuan pembelajaran. Hubungan filmdengan tujuan pembelajaran. Film untuk tujuan kognitif dapat digunakan untuk mengajarkan pengenalan makna sebuah konsep. Seperti konsep jujur, sabar, demokrasi dan lain-lain. Film untuk tujuan psikomotorik dapat digunakan untuk memerlihatkan contoh suatu keterampilan yang harus ditiru. Misalnya keterampilan gerak karena media ini mampu untuk memperjelas gerak dan memperlambat atau mempercepatnya. Film paling tepat bila digunakan untuk mempengaruhi sikap emosi.

2. Guru harus mengenal film yang tersedia dan terleih dahulu melihatnya untuk mengetahui manfaatnya bagi pelajaran.

3. Sesudah film dipertunjukkan perlu diadakan diskusi, yang juga perlu disiapkan sebelumnya

4. Adakalanya film tertentu dapat diputar dua kali atau lebih untuk memperhatikan bagianbagian tertentu.

5. Sesudah itu dapat di test berapa banyakkah yang dapat mereka tangkap dari film itu.

Penerapan media audio visual dalam pembelajaran PAI menurut penulis sangat membantu guru dan siswa dalam mencapai tujuan pendidikan. Dalam implementasinya guru dapat menggunakan media ini untuk mata pelajaran agama di madrasah atau sekolah berikut iini penulis mencoba untuk memberikan beberapa contoh penerapan media audio visual dalam pembelajaran PAI di madrasah. Mata pelajaran pendidikan agama islam di madrasah diantaranya adalah sejarah kebudayaan islam, fiqih, akidah akhlak, alqur'an hadits. Sejarah kebudayaan islam adalah kejadian atau peristiwa masa lampau yang berbentuk hasil karya, karsa dan cipta umat Islam yang didasarkan kepada sumber nilai-nilai Islam.

Mata pelajaran SKI di madrasah banyak membahas tentang sejarah masa lalu dalam perkembangan islam dan merasa kesulitan karena pembahasannya adalah berkisar tentang kejadian masa lalu yang siswa tidak melihat dan merasakan kejadian tersebut jadi dengan menggunakan media audio visual diharapkan penyajian materi ini akan lebih mudah untuk disampaikan informasinya (kontennya) kepada siswa. Mata pelajaran Al-qur'an hadits juga akan lebih menarik jika disajikan dengan media audio visual. Demikian juga dengan mata pelajaran yang lain seperti fiqih dan akidah akhlak.

\section{PENUTUP}

Media Pendidikan Agama Islam dapat diartikan semua aktifitas yang ada hubungannya dengan materi pendidikan agama Islam, baik yang berupa alat yang dapat diperagakan maupun teknik/metode yang secara efektif dapat digunakan oleh guru agama dalam rangka mencapai tujuan tertentu dan tidak bertentangan dengan ajaran Islam. Tujuan penggunaan media pembelajaran pendidikan agama Islam tersebut adalah supaya proses pembelajaran pendidikan agama Islam dapat berlangsung dengan baik. Media pembelajaran pendidikan agama Islam dapat diklasifikasikan menjadi dua jenis, yakni media yang bersifat materi dan media yang bersifat nonmateri. Penyelenggaraan media pendidikan Islam harus mendasarkan kepada dua prinsip, yaitu: (1) Memudahkan dan tidak mempersulit, dan (2) Menggembirakan dan tidak menyusahkan. Dalam menerapkan media pembelajaran pendidikan agama Islam harus dilakukan cara yang tepat dan praktis yang sesuai dengan kebutuhan peserta didik, sehingga dalam proses belajar mengajar 
dapat berjalan dengan efektif dan efisien. Selain hal tersebut pemilihan metode mengajar yang sesuai dengan media pembelajaran juga sangat penting karena akan berdampak pada tercapainya tujuan pembelajaran. Media audio memiliki kemampuan media untuk membangkitkan rangsangan indera pendengaran. Adapun ciri utama dari media ini adalah pesan yang dituangkan melalui audio dituangkan dalam lambang-lambang auditif, baik verbal maupun noverbal.

Media berbasis visual memegang peranan penting dalam proses belajar. Media visual dapat pula memperlancar pemahaman dan memperkuat ingatan. Visual dapat juga menumbuhkan minat siswa dan dapat memberikan hubungan antara isi materi dengan dunia nyata. Media audio visual adalah jenis media yang lain mengandung unsur suara juga mengandung unsur gambar yang bisa dilihat, seperti misalnya rekaman video, berbagai ukuran film, slide suara dan lain sebagainya. Kemampuan media ini dinggap lebih baik dan lebih menarik.

Media audio visual dapat dibagi menjadi dua jenis. Jenis pertama, dinamakan media audiovisual murni, seperti film gerak (movie) bersuara, televisi dan video. Jenis kedua adalah audi visual tidak murni yakni apa yang kita kenal dengan slide, opaque, ohp dan pralatan visual lainnya, bila diberi unsur suara dari rekaman kaset yang dimanfaatkan secara bersamaan dalam satu waktu atau proses pembelajaran. Penerapan media audio, visual dan audio visual dalam pembelajaran pendidikan agama islam menurut penulis sangat baik karena dapat meningkatkan efektifitas penyajian materi pendidikan agama islam di sekolah atau madrasah. Dengan menggunakan media tersebut materi pelajaran dapat disajikan dengan lebih menarik dan suasana pembelajaran dapat efektif.

\section{DAFTAR RUJUKAN}

Arsyad, A. (2010). Media pembelajaran. Jakarta: Rajawali Pers.

Drajat, Z. (2020). Ilmu Pendidikan Islam,. Jakarta: Bumi Aksara.

Ely, G. d. (1980). Teaching \& Media A Systematic Approach. second edition, By V.S Gerlach dan Ely. Person Education.

Ermawati. (2014). Pemanfaatan Media Pembelajaran Audio Visual untuk Meningkatkan Hasil Belajar PAI pada siswa Kelas V SDN kalianget Timur X.(Online). PEDAGOGIA Vol. 3, No.2.

Munadi, Y. (2013). Media pembelajaran Sebuab Pendekatan Baru. Jakarta: Referensi GP Press Group. Ramayulis. (2002). Ilmu Pendidikan Islam. Jakarta : Kalam Mulia.

Sanjaya, W. (2011). Perencanaan dan Desain Sistem Pembelajaran. Jakarta: Kencana .

Zain, S. B. (2002). Strategi Belajar Mengajar. Jakarta: Rineka Cipta.

Hidayati, Ani Nur. (2017). Implementasi Kurikulum 2013 Revisi 2017 Pada Pendidikan Agama Islam. (Online). (https://bdksemarang.kemenag.go.id/implementasi-kurikulum-2013 revisi2017-pada-pendidikan-agama-islam/, diakses 16 Februari 2019)

Nofiana, Mufida. (2016). 'Pengembangan Instrumen Evaluasi Higher Order Thinking Skills Pada Materi Kingdom Plantae', Pedagogi Hayati, 1 (2016) Prastya, Agus.2016. Strategi Pemilihan Media Pembelajaran Bagi Seorang Guru. Prosiding Temu Ilmiah Nasional Guru (Ting) Viii. (Online). (http://Repository.Ut.Ac.Id/6518/1/Ting2016st2 03.Pdf, Diakses 16 Februari 2019)

Wina, Demi Roma, dkk. 2017. Studi Kasus Pendekatan Saintifik dalam Pembelajaran IPA pada Kurikulum 2013 di SMP Negeri 5 Semarang. Journal of Innovative Science Education. (Online), Vol 6 (1), 2017. (http://journal.unnes.ac.id/sju/index.php/jise, diakses 16 Februari 2019) 